\title{
Assessing the Impact of Firm Reputation on Performance: An International Point of View
}

\author{
Ernest H. Hall Jr. ${ }^{1} \&$ Jooh Lee ${ }^{2}$ \\ ${ }^{1}$ Romain College of Business, University of Southern Indiana, Evansville, Indiana, United States \\ ${ }^{2}$ Rohrer College of Business, Rowan University, Glassboro, New Jersey, United States \\ Correspondence: Ernest H. Hall Jr., Romain College of Business, University of Southern Indiana, Evansville, \\ Indiana, 47712, United States. Tel: 1-812-465-7038. E-mail: ehall@usi.edu
}

Received: August 25, 2014

Accepted: November 18, 2014

Online Published: November 25, 2014

doi:10.5539/ibr.v7n12p1

URL: http://dx.doi.org/10.5539/ibr.v7n12p1

\begin{abstract}
In order to operationalize difficult concepts (corporate reputation, corporate social responsibility, and stakeholder orientation) researchers have generally turned to the Fortune Reputation Index (FRI) as a readily available measure. Despite the heavy reliance on the Fortune Reputation Index as a valid measure of a firm's reputation or social responsibility, the results of a study conducted by Fryxell \& Wang (1994) questioned the usefulness of the FRI as it is currently constituted. To be more specific, it has been suggested that the FRI is merely an amalgamation of financial metrics that reflects a firm's overall financial health. In response to such an accusation, more recent research conducted by Lee \& Hall (2008) that revalidates the veracity of the FRI. Even after controlling for any financial "halo" effects, the validity of the FRI as an acceptable proxy for firm reputation and social responsibility has been reestablished. In an effort to extrapolate on these more recent findings, the present study seeks to investigate corporate reputation from an international context. Results confirm a positive correlation between firm performance and firm reputation and highlight the importance of firm reputation as a critical strategic asset that needs to be managed.
\end{abstract}

Keywords: corporate reputation, international business, performance

\section{Introduction}

What is the value of a firm's reputation? How important is reputation to a firm's financial future? Despite the attention that this subject has garnered over the years, exactly how firm reputation and firm performance are related has remained a mystery to the present time. Does superior financial performance make a firm more attractive in the eyes of the business community? Or does a solid reputation subsequently lead to and enhance a firm's financial performance? Such a quandary remains a chicken or the egg puzzle that has baffled scholars for ages. Developing and maintaining a favorable reputation should pay dividends. Firms with better reputations may be afforded the benefit of charging higher prices for their goods and services (Klein \& Leffler, 1981; Milgrom \& Roberts, 1986). A positive reputation is also likely to influence customer preferences and their buying behavior (Dowling, 1986). A strong reputation may also suppress or minimize competitive rivalry within an industry (Caves \& Porter, 1977; Wilson, 1985), and/or increase a firm's social status (Shrum \& Wuthnow, 1988).

The opposite could also be true, given that a firm is normally rewarded by the financial community for being socially responsible and developing a good corporate reputation. A firm's stakeholders will likely reward firms for acting in a socially responsible and this should allow a firm to garner greater profits and therefore, greater financial returns. The issue of causality is not the objective of the present study. However, the present study seeks to address two major issues: 1) What is the relationship between reputation and performance, and 2) Does the reputation-performance linkage generalizable to other countries or is this just an American phenomenon. Therefore, an international sample will be employed to address these questions.

\section{Literature Review}

\subsection{Corporate Reputation}

Corporate reputation can be defined as the stakeholders' assessment of a firm's long-term assessment of a organization's social and economic potential by its stakeholders (e.g. customers, suppliers, society, etc.). 
Corporate reputation is considered a critical asset in a firm's "strategic arsenal" (Barney, 1991). Therefore, executive managers need to be continuously aware of how their decisions will impact the organization's reputation. Or from a different perspective, according to Fombrun (1996, p. 72), corporate reputation can be defined as "a perceptual representation of a company's past actions and future prospects that describe the firm's overall appeal to all its key constituents when compared to other leading rivals." Regardless of the exact perspective or point-of-view selected, the general conclusion has been that reputation is valuable and essential asset for any firm. Such a critical asset must be protected and nourished, so that the firm will have the opportunity to reap superior financial rewards.

Since a firm's reputation may be considered a strategic resource, it is imperative that a firm take a proactive stance with regard to managing such a vital strategic resource (Barney, 1991). Illusiveness, a key characteristic of the construct of corporate reputation, offers a firm the opportunity to build a sustainable competitive advantage, which is not subject to imitation. For example, look at Toyota and how many companies have attempted to duplicate their reputation for quality. Due to its very nature, reputation is a hard to measure construct. Roberts \& Dowling (2002, p. 1077) have stated that "Intangible assets — such as good reputations - are critical because of their potential for value creation, but also because their intangible character makes replication by competing firms considerably more difficult." Based upon this logic, it can be argued that the non-quantifiable nature of the construct of reputation is the essence of the ultimate value. Such a situation can be referred to as "causal ambiguity." As cited by others, causal ambiguity is suggested as a source for developing a sustainable competitive advantage (Lippman \& Rumelt, 1982).

In addition, a firm's response to a crisis or stand on an ethical issue will invariably have an effect, whether negative or positive, on how the firm is perceived, i.e. their reputation/image. How a firm responds to a crisis and how it regularly conducts business is under constant scrutiny by a plethora of constituencies (both internal and external). Examples of effective (e.g. Johnson \& Johnson's response to contaminated Tylenol) and ineffective (e.g. Exxon's Valdez oil spill in Alaska) crisis management may either positively or negatively impact a firm's image and, therefore, its reputation. However, one thing seems to be certain, if a firm has negative reputational quotient, the it will have dampening effect on a firm's future profitability and even its survival. The important thing to remember is that whether the reputation is justifiably accurate or not does not matter. The impact of reputation will be reflected on Wall Street and felt by the shareholders regardless of accuracy.

As argued by Fombrun \& Shanley (1990) reputation management can go a long way in determining a firm's long-term financial performance. The establishment of a good or positive corporate reputation can benefit a company in many ways: 1) affecting the choices that customer make in selecting a product (Dowling, 1986), 2) limiting the potential competitive moves of rivals (Caves \& Porter, 1977; Wilson, 1985), and 3) securing a certain social status within an industry (Shrum \& Wuthnow, 1988). The result of all of these benefits is that a firm is likely to experience an increase in profitability, market share, and a strengthening of their competitive advantage. As can be seen, the benefits of developing and maintaining a good corporate reputation can be extremely beneficial to a firm's long-term success.

When corporate reputation has been included in studies within the management discipline the primary emphasis has been on its effect on financial potential (Fombrun \& Shanley, 1990; McGuire et al., 1988). Based on the results of such studies it would be expected that a positive reputation would exhibit a positive effect on firm performance (Caves \& Porter, 1977; Fombrun \& Shanley, 1990; McGuire et al., 1988), although the issue of causality has not been investigated. Nevertheless, the presence of a positive or favorable corporate reputation should help an organization out-perform firms that possess a less than favorable reputation. Exactly why or how this occurs has been the subject of much controversy.

The potential influence of a firm's reputation has continued to be a source of interest for researchers and practitioners alike for a long time. However, the elusive nature of reputation has stymied researchers from pursuing more intensive studies on the subject. Given the extensive globalization of business over the past decade, it can be argued that the connection between a firm's corporate reputation and performance should be readdressed from an international perspective. Up to the point in time the extant literature has focused solely on U.S. firms due to a dearth of data on international firms. However, thanks to Fortune's annual publication of the "World's Most Admired Companies" data can now be gathered to assist in understanding the connection between reputation and financial performance from an international perspective. Given that a positive connection between a favorable reputation and superior performance has been consistently shown within the context of U.S. firms, the present study seeks to examine whether this relationship extends to other countries.

It should be clearly stated that not all studies are complementary when it comes to discussing the Fortune 
Reputation Index. The most severe criticism comes from a study conducted by Fryxell \& Wang (1994) that concluded that the FRI is merely a reflection or composite measure of financial performance. The logic of this argument is that the FRI is more of a measure of how well a firm is performing financially, than how well respected the firm is within its industry. The inevitable question arises: Is it possible that the FRI is nothing more than a reflection or measure of a firm's profitability? If such a hypothesis can be proven to be accurate, then all of the results and conclusions from previous research, which employing the FRI, would be called into question.

However, in a more recent study by Lee \& Hall (2008) evidence was presented that validated the FRI as a robust measure of reputation. Accordingly, after removing the effects of financial performance, it was determined that the FRI is a very good indicator of a firm's overall corporate reputation (Lee \& Hall, 2008). For a more detailed analysis of the exact methodology employed in the removal of what has come to be known as the "financial halo effect" of the FRI, please see Brown \& Perry (1994) and Lee \& Hall (2008).

Based on these studies, it is not the purpose of this study to dissect the FRI and undertake an investigation into the deep theoretical underpinnings of the reputation construct. Instead, we employ and present the FRI as a valid and robust proxy of corporate reputation and reject the argument that the FRI is nothing more than a measure of financial performance. Within the context of the reputation and performance literature, the present study will incorporate accounting- and market-based variables in assessing the effects of an organization's reputation on performance. Results suggest that the impact of a favorable corporate reputation on a firm's financial performance is consistent across both U.S. and Japan firms.

\subsection{The Diversification-Performance Linkage}

Firm performance has been widely linked to a firm's diversification profile by a variety of studies (Bettis, 1981; Bettis \& Hall, 1982; Dess, Gupta, Hennart, \& Hill, 1995; Palepu, 1985; Rumelt, 1974). Therefore, it is critical to assess the influence and effects of a firm's diversification profile on performance when proposing a study to explain firm performance. Failing to account for any effects that diversification may have on a firm's profitability could potentially lead to erroneous conclusions when seeking to uncover a reputation-performance linkage. Indeed, in some cases diversification is promoted as a vehicle for improving firm performance or enhancing a firm's strategic competitiveness, which may have an impact on a firm's reputation. Porter (1990) suggests that diversification is an avenue or pathway for expanding a firm's assets, resources, and skills that can help to expand the number of value adding activities that are available to their organization. These critical factors are likely to contribute to the firm developing a positive reputation.

As the pace of globalization has quickened in recent years, two different perspectives have developed within the strategy literature that may be considered germane to the discussion at hand; 1) product diversification, and 2) market or what is sometimes referred to as international diversification. Viewed from a traditional, product diversification perspective, firms will diversify in an attempt to purchase or develop new and different product from their current portfolio. The goal of such a strategy is ultimately, profit directed. Through the addition of new products to the portfolio the firm is able to increase their product line and in turn, their revenue stream and profits. It is the intent of such a diversification strategy to enter and/or develop new markets, which are not currently being served by the firm (product development strategy). By following such a strategy a firm is able to increase its profits by entering new markets and industries. The end result of this strategy is that the firm has increased the number of industries and markets in which it operates, thus affording it great opportunities to make profits.

From an international perspective, when a firm engages in a market diversification strategy the objective is to exploit the potential product demand for current products in other countries. Such a strategy does not include developing new products, but merely transferring an existing product to a new country. As opposed to a product-oriented strategy, a market diversification strategy seeks to serve international markets/countries by relying on their existing business portfolio. This is why such a strategy is frequently referred to as international diversification. Likewise, the focus on marketing existing products to new countries explains why some refer to such a strategy as a market-based diversification strategy.

In order to put it more succinctly, a product diversification perspective seeks to develop new industries or products, while a market- or international diversification strategy is directed at exploiting demand in new countries utilizing existing businesses/products (Grant, Jammine, \& Thomas, 1988). The influence of a diversification strategy may have a direct relationship with the overall reputation that an organization has earned over the years, due to a firm's increased level of status and size. Regardless of the overall impact that diversification may play in enhancing a firm's reputation and therefore, directly contributing to the overall FRI, it is critical to control and manage the influence of diversification on performance. 


\section{Hypotheses}

Based upon the preceding discussion several hypotheses present themselves concerning the relationships among the variables of CEO compensation, corporate reputation, and CEO personal characteristics, as well as controlling for industry, career path, and financial performance effects. Given the current state of research on the topics covered in this study, the following hypotheses present themselves:

$\mathrm{H}_{1}$ : Corporate reputation will be positively related with firm performance after controlling for diversification and other strategic variables.

$\mathrm{H}_{1 \mathrm{a}}$ : Corporate reputation for U.S. firms will be positively related with firm performance after controlling for diversification and other strategic variables.

$\mathrm{H}_{1 b}$ : Corporate reputation for Japanese firms will be positively related with firm performance after controlling for diversification and other strategic variables.

$\mathrm{H}_{2}$ : For both U.S. and Japanese firms, product diversification will be negatively related with firm performance after controlling for other strategic variables.

$\mathrm{H}_{3}$ : For both U.S. and Japanese firms, international diversification will be positively related with firm performance after controlling for other strategic variables.

\section{Methodology}

\subsection{Sample}

The primary data source for the sample being used in this study was the "World's Most Admired Companies" published by Fortune magazine for the years 2007-2011. The Fortune 2007 issue served as the focal point and set the initial parameters for the initial sample (a total of 354 firms were listed). After looking at a statistical breakdown by country of the firms listed on the "World's Most Admired Companies" over the five-year period to be studied, it was decided to focus on a comparative study of only two countries, the U.S. (103 firms) and Japan (72 firms). The small sample sizes for the other countries disqualified them from inclusion in the study.

A total of 175 firms from the U.S. and Japan met all of the criteria to be included in the sample. Financial information for each firm was derived from Compact Disclosure (U.S. firms), Worldscope (Japanese firms) and The Directory of Multinationals (Stockton Press). In order to insure that the data were not unduly impacted by disruptions from a single year, a five-year average was used to provide a more longitudinal assessment of the variables being studied. A multi-year measure of the variables was believed to provide a more dynamic and robust evaluation of the reputation/performance linkage.

To allow for adjustments in a firm's overall diversification footprint or other factors that might have an effect on a firm's reputation it is argued that a five-year timeframe would allow for any necessary corrections to be reflected in a firm's financial statements. Utilizing a longer timeframe than most studies allows for changes and adjustments to a firm's strategy to be incorporated into the organization and subsequently, reflected in an organization's reputation and financial performance (Keats, 1990). The use of averages afforded the opportunity to avoid confounding and misleading issues related to one-time events that can unduly influence the statistical results. To maintain the comparability of the database used in the study a decision was made to only include firms with complete data across all the variables in the study. Although such a rigid rule limited the overall sample size, it was decided that the advantages of having complete data on all companies in the study would bolster the overall strength of the research study.

\subsection{Measurement of Variables}

In an attempt to strengthen the impact of the current study, a variety of variables were selected and included based on prior research studies on corporate reputation and diversification. In an attempt to provide a thorough investigation on the subject of reputation, the following variables and their corresponding measures were chosen to operationalize the variables being investigated.

\subsubsection{Performance Measures}

Identified as the performance measure of choice among strategy scholars, the accounting-based variables for firm performance have been widely recognized as an essential to studies on diversification. Based on previous studies the following four measures of performance were adopted: return on assets (ROA), return on sales (ROS), return on equity (ROE) (Delios \& Beamish, 1999; Geringer, Beamish, \& da Costa, 1989; Geringer, Tallman, \& Olsen, 2000; Kim, Whang, \& Burgers, 1989; Tallman \& Li, 1996), and Tobin's Q (Amit \& Livnat, 1988).

Measuring financial performance from an accounting perspective was accomplished in the following manner: 


$$
\begin{gathered}
R O A=(\text { Profit After-Tax }) /(\text { Assets }) \\
\text { ROE }=(\text { Profit After-Tax }) /(\text { Common Stockholder's Equity }) \\
\text { ROS }=(\text { Profit After }- \text { Tax }) /(\text { Sales })
\end{gathered}
$$

In an attempt to more fully assess a firm's performance a market-based measure was also utilized. Tobin's $\mathrm{Q}$ is frequently employed as a future-oriented measure of firm performance (Finkelstein \& Boyd, 1998; Lu \& Beamish, 2004; Miller, 2004). It has been argued by some (Amit \& Livnat, 1988) that Tobin's Q is a reflection of investors' expectations and the performance possibilities of an organization in the future. Therefore, Tobin's Q represents a different perspective than the historical view of accounting-based measures. For the purposes of this study, Tobin's Q was calculated in the following manner:

Tobin's $Q=$ (Market Value of Equity + Liquidating Value of Preferred Stock + Value of Total Debt)/Total Assets

\subsubsection{Product Diversification}

Although a firm's level of diversification can be operationalized in a variety of ways, one of the most frequently utilized indices of diversification is what is commonly referred to as the Herfindahl index. Research studies have suggested that the Herfindahl index is a useful measure of a firm's level of diversification that stands up to the rigors of tests for reliability and validity. Inn simple terms, the Herfindahl index is an assessment of the ratio of business segment sales to overall company sales. The Herfindahl index was used to assess the depth of product diversification (HPDVSF) by a firm and was calculated using the following formula:

$$
H P D V S F=1-\Sigma S_{j}^{2}
$$

where:

$\mathrm{S}_{\mathrm{i}}=$ the proportion of firm sales reported in business segment ${ }_{\mathrm{j}}$

A score of zero on the Herfindahl index reflects a firm that is engaged in a single business segment. Values greater than zero indicate increasing levels of product diversification.

\subsubsection{Market Diversification}

Market-based or international diversification was a reflection of firm sales obtained from doing business in overseas markets (i.e., export activity). Market or international diversification (MKDVSF) was measured using sales obtained from foreign operations and exports (Geringer et al., 1989; Grant et al., 1988; Rugman, 1994; Wolf, 1975), and was measured as:

$$
M K D V S F=F S_{i} / T S_{i}
$$

where:

$\mathrm{FS}_{\mathrm{i}}=$ sales/export volume of foreign trade in year $\mathrm{i} ; \quad i \quad i$

$\mathrm{TS}_{\mathrm{i}}=$ sales of the firm in year i.

The index used to assess market diversification measures increasing levels of foreign trade. Therefore, firms reporting higher levels of market diversification, as reflected in their index scores, are considered to be more engaged in international trade and exports than other firms.

\subsubsection{Strategic Resource Variables}

It is widely conceded that a variety of variables can have a profound impact on a firm's overall performance. Based on this commonly accepted premise, a number of variables were identified to be included in the study as control variables (Bergh, 1995; Chatterjee \& Wernerfelt, 1991; Lang \& Stulz, 1994; Tallman \& Li, 1996). After a thorough review of previous studies, the following strategic variables were identified as relevant and pertinent to the subject at hand: R \& D (Amit \& Livnat, 1988; Lang \& Stulz, 1994), financial leverage (DEBT, Grant et al., 1989; Hoskisson, Hitt, Johnson \& Moesel, 1993), firm size, and liquidity. A simple averaging technique was used in operationalizing these variables over the five-year period of the study:

$R \& D=R \& D$ Expenditures/Sales

DEBT leverage $=$ Book Value of Debt/Shareholders' Equity

SIZE $=$ Ln (Sales)

LIQUIDITY (current ratio) $=$ Current Assets $/$ Current Liabilities

\subsection{Statistical Methods}

To order to understand the relationship between a firm's reputation, level of diversification, and financial 
performance, a series of hierarchical regressions were employed to investigate the hypotheses previously outlined. The following model was used in testing the hypotheses.

Performance $=$ Stage 1 : Country (dummy variables)

Firm size

R\&D intensity

Debt leverage

Liquidity current ratio

Stage 2: Product Diversification

Market Diversification

Stage 3: Corporate reputation

It should be explicitly noted that issues of causality, while of great interest to academics and practitioners, was not one of the objectives of the study.

\section{Results and Discussion}

\subsection{Descriptive Statistics and Intercorrelations}

A list of descriptive statistics and intercorrelations for the variables included in the study can be found in Table 1 . Of the seven independent variables used in the study, which included one measure of corporate reputation, product- and market-based diversification, $R \& D$, leverage, firm size, and liquidity, only the liquidity variable did not show a significant correlation with any of the measures of performance. Such strong relationships among the variables included in the study seem to indicate that the variables that were included were good predictors of firm performance.

Table 1. Mean, standard deviation, and correlation: USA, JAPAN, \& EEC ${ }^{\mathrm{a}}$

\begin{tabular}{|c|c|c|c|c|c|c|c|c|c|c|c|c|c|c|c|c|}
\hline Variables & Mean & St.Dev. & 1 & 2 & 3 & 4 & 5 & 6 & 7 & 8 & 9 & 10 & 11 & 12 & 13 & 14 \\
\hline 1. USA (Dummy) & .449 & .499 & & & & & & & & & & & & & & \\
\hline 2. JAPAN (Dummy) & .316 & .466 & $-.62 * * *$ & & & & & & & & & & & & & \\
\hline 3. EEC (Dummy) & .238 & .427 & $-.50 * * *$ & $-.37 * * *$ & & & & & & & & & & & & \\
\hline 4. Average ROA & .092 & .087 & $.43 * * *$ & $-.44 * * *$ & -.02 & & & & & & & & & & & \\
\hline 5. Average ROE & .279 & .312 & $.35 * * *$ & $-.39 * * *$ & .02 & $.71 * * *$ & & & & & & & & & & \\
\hline 6. Average ROS & .097 & .109 & $.37 * * *$ & $-.39 * * *$ & $k-.01$ & $.84 * * *$ & $.54 * * *$ & & & & & & & & & \\
\hline 7. Tobin's Q & 1.853 & 2.024 & $.25 * * *$ & $-.23 * * *$ & -.05 & $.67 * * *$ & $.37 * * *$ & $.54 * * *$ & & & & & & & & \\
\hline 8. Firm Size:Ln (Sales) & 16.848 & .858 & .02 & .03 & -.05 & $.28 * * *$ & $.15^{*}$ & $.27 * * *$ & $.22 * * *$ & & & & & & & \\
\hline 9. DIVSF - Market & 1.023 & .421 & $-.31 * * *$ & .05 & $.32 * * *$ & $.26 * * *$ & $.23 * * *$ & $.23 * * *$ & $.18^{* * *}$ & $.19 * *$ & & & & & & \\
\hline 10. DIVSF - Product & .958 & .467 & $-.12+$ & -.02 & $.16^{*}$ & -.06 & -.05 & .05 & -.09 & -.07 & $.14 *$ & & & & & \\
\hline 11. R\&D Intensity & 3.993 & 3.876 & $.14 *$ & -.09 & -.07 & $.57 * * *$ & $.25^{* * *}$ & $.54 * * *$ & $.63 * * *$ & $.18 * *$ & $.30 * * *$ & .04 & & & & \\
\hline 13. Debt Leverage & .367 & .232 & -.08 & $.20 * *$ & $-.12+$ & $-.43 * * *$ & .00 & $-.35^{* * * *}$ & $*-.38 * * *$ & $-.15^{*}$ & $-.17 *$ & .07 & $-.35 * * *$ & $-.20 * *$ & & \\
\hline 14. Current Ratio & 32.358 & 69.178 & .10 & -.05 & -.06 & $.24 * * *$ & .07 & $.18^{* *}$ & .01 & .04 & .04 & .05 & $.16^{*}$ & .03 & $-.13 *$ & \\
\hline 15. Reputation Index & 5.697 & 1.184 & $.24 * * *$ & $-.28 * * *$ & .03 & $.41 * * *$ & $.29 * * *$ & $.34 * * *$ & $.35 * * *$ & $.29 * * *$ & $.14 *$ & $-.18 * *$ & $.25 * * *$ & $.26 * * *$ & $-.28 * * *$ & -.02 \\
\hline
\end{tabular}

${ }^{\mathrm{a}} \mathrm{n}=230 ;+\mathrm{P}<0.1 ; * \mathrm{P}<0.05 ; * * \mathrm{P}<0.01 ; * * * \mathrm{P}<0.001$.

Corporate reputation was highly correlated with all four measures of firm performance, suggesting that corporate reputation measures have a strong financial foundation. However, this does not mean that all of the variance reflected in firm performance was explained by a firm's reputation. Nevertheless, results suggest that corporate reputation was positively correlated with accounting- and market-based measures of performance, while firm reputation was negatively correlated with Japanese firms.

Firm profitability was also positively associated with firm size, market- and product diversification, and debt 
leverage and negatively associated with R\&D. Although it was interesting that $R \& D$ was negatively correlated with a firm performance, it may be explained by the direct relationship between R\&D expenditures and the bottom line of firm performance. It may be argued that a firm's reputation is more closely associated with a firm's ability to bring new products to market (what the FRI refers to as innovativeness) and not the mere activity that is reflected by $R \& D$ expenditures.

Surprisingly, neither market- or product-based diversification was significantly related to either U.S. or Japanese firms. Both market- and product-based diversification were positively correlated with all measures of performance, suggesting that diversification type may not be integral in determining performance.

\subsection{Results of Regression Analysis}

The aggregate sample (both U.S. and Japanese firms) was tested using techniques of hierarchical regression. Subsequent to that, two separate samples were utilized to look for country-specific differences. Results from the regression analyses can be found in Tables $2 \mathrm{a}, 2 \mathrm{~b}$, and 3 . All the estimated regression models reached significant $(\mathrm{p}<.001)$, suggesting that the models that were estimated were useful in explaining performance differences among the samples.

Table 2a. Results of the Hierarchical regression analysis estimating firm performance: USA ${ }^{\mathrm{a}}$

\begin{tabular}{|c|c|c|c|c|c|c|c|c|c|c|c|c|}
\hline & \multicolumn{3}{|c|}{ Return on Assets } & \multicolumn{3}{|c|}{ Return on Sales } & \multicolumn{3}{|c|}{ Return on Equity } & \multicolumn{3}{|c|}{ Tobin's Q } \\
\hline & Step 1 & Step 2 & Step 3 & Step 1 & Step 2 & Step 3 & Step 1 & Step 2 & Step 3 & Step 1 & Step 2 & Step 3 \\
\hline \multirow[t]{2}{*}{ Constant } & $-0.383^{*}$ & $-0.351^{*}$ & $-0.331^{*}$ & $-0.692^{* * *}$ & $-0.637^{* * *}$ & $-0.608^{* * *}$ & $-1.081^{*}$ & $-1.097^{*}$ & $-1.051^{*}$ & $-10.48^{* * *}$ & $-10.85^{* * *}$ & $-11.21^{* * *}$ \\
\hline & $(.152)$ & (.148) & $(.143)$ & $(.167)$ & $(.171)$ & $(.162)$ & $(.489)$ & (.483) & $(.523)$ & (3.12) & (3.13) & (3.03) \\
\hline \multirow[t]{2}{*}{ Firm Size-Ln(Sale) } & $0.029^{* *}$ & $0.026^{* *}$ & $0.016^{*}$ & $0.052^{* * *}$ & $0.049^{* * *}$ & $0.037^{* * *}$ & $0.073^{*}$ & $0.068^{*}$ & $0.078^{*}$ & $1.032^{* * *}$ & $0.966^{* * *}$ & $0.708^{* * * *}$ \\
\hline & $(.001)$ & $(.009)$ & $(.007)$ & $(.011)$ & $(.012)$ & $(.010)$ & $(.034)$ & $(.032)$ & $(.034)$ & $(.252)$ & $(.251)$ & $(.256)$ \\
\hline \multirow[t]{2}{*}{ R\&D Intensity } & $0.008^{* * *}$ & $0.006^{* *}$ & $0.006^{* *}$ & $0.009^{* * *}$ & $0.013^{* * *}$ & $0.01^{* * *}$ & $0.029^{* * *}$ & $0.017^{*}$ & $0.016^{*}$ & $0.324^{* * *}$ & $0.334^{* * *}$ & $0.317^{* * *}$ \\
\hline & $(.002)$ & $(.002)$ & $(.002)$ & $(.002)$ & $(.002)$ & $(.002)$ & $(.007)$ & $(.007)$ & $(.007)$ & $(.050)$ & $(.057)$ & $(.055)$ \\
\hline \multirow[t]{2}{*}{ Debt Leverage } & -0.037 & $-0.055^{*}$ & $-0.053+$ & -0.046 & -0.035 & -0.025 & $-0.416^{* *}$ & $-0.392^{* *}$ & $-0.409^{* *}$ & -1.481 & -1.344 & -1.122 \\
\hline & $(.031)$ & $(.028)$ & $(.028)$ & $(.041)$ & $(.041)$ & (.039) & (.136) & (.138) & (.137) & $(1.01)$ & (1.02) & $(.976)$ \\
\hline \multirow[t]{2}{*}{ Current Ratio } & 0.002 & $0.003^{+}$ & $0.002^{*}$ & 0.002 & 0.001 & 0.001 & 0.001 & 0.001 & 0.001 & $0.002^{*}$ & $0.003^{* *}$ & $0.003^{* *}$ \\
\hline & $(.001)$ & $(.003)$ & $(.003)$ & $(.003)$ & $(.002)$ & $(.001)$ & $(.002)$ & $(.001)$ & $(.001)$ & $(.002)$ & $(.001)$ & $(.001)$ \\
\hline \multirow[t]{2}{*}{ Market Diversification } & & $0.072^{* *}$ & $0.066^{* *}$ & & $0.032^{* * *}$ & $0.308^{* * *}$ & & $0.313^{* *}$ & $0.298^{* *}$ & & 0.387 & $0.435^{* *}$ \\
\hline & & $(.024)$ & $(.023)$ & & $(.086)$ & $(.008)$ & & $(.087)$ & $(.087)$ & & $(.197)^{*}$ & $(.186)^{*}$ \\
\hline \multirow[t]{2}{*}{ Product Diversification } & & -0.025 & -0.013 & & -0.025 & -0.009 & & -0.032 & 0.002 & & -0.354 & -0.298 \\
\hline & & $(.015)$ & $(.015)$ & & $(.017)$ & $(.017)$ & & $(.048)$ & $(.057)$ & & $(.275)$ & (0213) \\
\hline \multirow[t]{2}{*}{ Corporate Reputation } & & & $0.021^{* *}$ & & & 0.027 & & & $0.051^{*}$ & & & 0.397 \\
\hline & & & (.007) & & & $(.008)^{* * * *}$ & & & $(.027)$ & & & $(.234)^{* *}$ \\
\hline Model $\mathrm{R}^{2}$ & 0.379 & 0.457 & 0.462 & 0.306 & 0.322 & 0.384 & 0.302 & 0.387 & 0.409 & 0.406 & 0.422 & 0.484 \\
\hline Adjusted $\mathrm{R}^{2}$ & 0.357 & 0.432 & 0.435 & 0.275 & 0.279 & 0.339 & 0.263 & 0.342 & 0.358 & 0.375 & 0.379 & 0.439 \\
\hline Model F-Ratio & $26.394^{* * *}$ & $25.73^{* * *}$ & $22.57^{* * *}$ & $13.141^{* * *}$ & $9.818^{* * *}$ & $10.89^{* * *}$ & $8.21^{* * *}$ & $8.487^{* * *}$ & $8.047^{* * * *}$ & $13.14^{* * *}$ & $9.818^{* * *}$ & $10.89^{* * * *}$ \\
\hline Change in $\mathrm{R}^{2}$ & & 0.078 & 0.005 & & 0.016 & 0.061 & & 0.085 & 0.022 & & 0.016 & 0.061 \\
\hline \multicolumn{13}{|l|}{ F-ratio for Change in } \\
\hline $\mathrm{R}^{2}$ & 26.394 & 10.72 & 0.813 & 13.141 & 1.302 & 11.03 & 8.211 & 6.731 & 3.431 & 13.14 & 1.302 & 11.03 \\
\hline
\end{tabular}

\footnotetext{
${ }^{a} n=103$. Unstandardized regression coefficients are shown and Standard errors are in parantheses.
}

$+\mathrm{P}<0.1 ; * \mathrm{P}<0.05 ; * * \mathrm{P}<0.01 ; * * * \mathrm{P}<0.001$. 
Table 2b. Results of the Hierarchical regression analysis estimating firm performance: Japan ${ }^{\mathrm{a}}$

\begin{tabular}{|c|c|c|c|c|c|c|c|c|c|c|c|c|}
\hline & \multicolumn{3}{|c|}{ Return on Assets } & \multicolumn{3}{|c|}{ Return on Sales } & \multicolumn{3}{|c|}{ Return on Equity } & \multicolumn{3}{|c|}{ Tobin's Q } \\
\hline & tep 1 & p 2 & tep 3 & tep 1 & 2 & Step 3 & Step 1 & Step 2 & Step 3 & tep 1 & Step 2 & Step 3 \\
\hline Constant & $\begin{array}{c}-0.289^{*} \\
(.123)\end{array}$ & $\begin{array}{c}-0.286^{*} \\
(.123)\end{array}$ & $\begin{array}{c}-0.258^{* *} \\
(.122)\end{array}$ & $\begin{array}{c}-0.332 * \\
(.152)\end{array}$ & $(.179)$ & $\begin{array}{c}-0.307 * \\
(.170)\end{array}$ & $\begin{array}{c}-0.539 * \\
(.301)\end{array}$ & $\begin{array}{c}-0.528^{*} \\
(.304)\end{array}$ & $\begin{array}{c}-0.566 * \\
(.307)\end{array}$ & $\begin{array}{c}-0.563 * \\
(.263)\end{array}$ & $\begin{array}{c}-0.456^{*} \\
(.175)\end{array}$ & $\begin{array}{c}-0.458 * \\
(.176)\end{array}$ \\
\hline Firm & $\begin{array}{c}0.023^{* * *} \\
(.007)\end{array}$ & $\begin{array}{c}0.022^{* *} \\
(.008)\end{array}$ & $\begin{array}{l}0.018^{*} \\
(.008)\end{array}$ & $\begin{array}{l}0.024^{*} \\
(.010)\end{array}$ & $\begin{array}{c}0.028 * * \\
(.011)\end{array}$ & $\begin{array}{c}0.029 * * \\
(.012)\end{array}$ & $\begin{array}{c}0.037 * \\
(.018)\end{array}$ & $\begin{array}{c}0.035^{*} \\
(.014)\end{array}$ & $\begin{array}{c}0.047 * \\
(.022)\end{array}$ & $\begin{array}{l}0.321 * \\
(.157)\end{array}$ & $\begin{array}{c}0.287 * \\
(.144)\end{array}$ & $\begin{array}{c}0.085^{* *} \\
(.032)\end{array}$ \\
\hline$R \& D I$ & $\begin{array}{l}-0.004 \\
(.002)\end{array}$ & $\begin{array}{l}-0.004 \\
(.003)\end{array}$ & $\begin{array}{l}-0.004 \\
(.003)\end{array}$ & $\begin{array}{c}0.103 * * \\
(.041)\end{array}$ & $\begin{array}{c}0.032 * \\
(.015)\end{array}$ & $\begin{array}{c}0.032 * \\
(.014)\end{array}$ & $\begin{array}{l}0.001 \\
(.002)\end{array}$ & $\begin{array}{c}0.032 * \\
(.015)\end{array}$ & $\begin{array}{c}0.031 * \\
(.015)\end{array}$ & $\begin{array}{c}0.129 * * \\
(.048)\end{array}$ & $\begin{array}{c}0.131 \text { ** } \\
(.046)\end{array}$ & $\begin{array}{c}0.132 * * \\
(.049)\end{array}$ \\
\hline Debt 1 & $\begin{array}{c}-0.111^{* * *} \\
(.023)\end{array}$ & $\begin{array}{c}-0.085 * * \\
(.028)\end{array}$ & $\begin{array}{c}-0.061 * \\
(.031)\end{array}$ & $\begin{array}{l}-0.255 \\
(.162)\end{array}$ & $\begin{array}{l}-0.241 \\
(.161)\end{array}$ & $\begin{array}{l}-0.045 \\
(.043)\end{array}$ & $\begin{array}{l}0.121^{*} \\
(.054)\end{array}$ & $\begin{array}{c}0.173 * \\
(.070)\end{array}$ & $\begin{array}{c}0.133 * \\
(.057)\end{array}$ & $\begin{array}{l}-0.423 \\
(.493)\end{array}$ & $\begin{array}{l}-0.401 \\
(.326)\end{array}$ & $\begin{array}{l}-0.308 \\
(.345)\end{array}$ \\
\hline Current Ratio & $\begin{array}{l}0.001 \\
(.001)\end{array}$ & $\begin{array}{l}0.002 \\
(.001)\end{array}$ & $\begin{array}{l}0.001 \\
(.001)\end{array}$ & $\begin{array}{l}0.001 \\
(.001)\end{array}$ & $\begin{array}{l}0.001 \\
(.001)\end{array}$ & $\begin{array}{l}0.001 \\
(.002)\end{array}$ & $\begin{array}{l}0.001 \\
(.001)\end{array}$ & $\begin{array}{l}0.002 \\
(.001)\end{array}$ & $\begin{array}{l}0.001 \\
(.001)\end{array}$ & $\begin{array}{c}0.007 * \\
(.003)\end{array}$ & $\begin{array}{c}0.006^{*} \\
(.003)\end{array}$ & $\begin{array}{c}0.007 * \\
(.003)\end{array}$ \\
\hline Market Diversification & & $\begin{array}{c}0.062^{* * *} \\
(.011)\end{array}$ & $\begin{array}{c}0.063^{* * *} \\
(.012)\end{array}$ & & $\begin{array}{c}0.313^{* * *} \\
(.083)\end{array}$ & $\begin{array}{c}0.346^{* * * *} \\
(.018)\end{array}$ & & $\begin{array}{c}0.313^{* * *} \\
(.083)\end{array}$ & $\begin{array}{c}0.346^{* * * *} \\
(.030)\end{array}$ & & $\begin{array}{c}0.423 * \\
(.272)\end{array}$ & $\begin{array}{c}0.389^{*} \\
(.286)\end{array}$ \\
\hline Produ & & $\begin{array}{c}-0.023^{*} \\
(.012)\end{array}$ & $\begin{array}{l}-0.019 \\
(.012)\end{array}$ & & $\begin{array}{l}-0.026 \\
(.018)\end{array}$ & $\begin{array}{l}-0.016 \\
(.017)\end{array}$ & & $\begin{array}{l}-0.523 \\
(.030)\end{array}$ & $\begin{array}{l}-0.053 \\
(.031)\end{array}$ & & $\begin{array}{c}0.155^{*} \\
(.070)\end{array}$ & $\begin{array}{c}0.176 \\
(.073) *\end{array}$ \\
\hline Corpo & & & $\begin{array}{c}0.016^{*} \\
(.008)\end{array}$ & & & $\begin{array}{c}0.037^{* *} \\
(.012) \\
\end{array}$ & & & $\begin{array}{c}0.065^{* *} \\
(0.27) \\
\end{array}$ & & & $\begin{array}{c}0.062 * \\
(.027) \\
\end{array}$ \\
\hline & 0 . & 0.347 & 0351 & 0. & 03 & 0.388 & 0.302 & 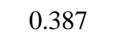 & 0.409 & 0.408 & 0.449 & 0.451 \\
\hline Adjusted R2 & 0.284 & 0.316 & 0.316 & 0.292 & 0.294 & 0.304 & 0.263 & 0.342 & 0.358 & 0.367 & 0.395 & 0.387 \\
\hline Model F-Ratio & $19.255^{* * *}$ & $20.47 * * *$ & $21.51^{* * *}$ & $19.896^{* * *}$ & $14.605^{* * *}$ & $15.68 * * *$ & $8.211^{* * *}$ & $8.487 * * *$ & $8.047 * * *$ & $12.39 * * *$ & $10.1^{* * *}$ & $8.721 * * *$ \\
\hline Change in R2 & & 0.131 & 0.004 & & 0.016 & 0.051 & & 0.089 & 0.022 & & 0.041 & 0.001 \\
\hline F-ratio for Change in $\mathrm{R}^{2}$ & 19.255 & 15.01 & 0.955 & 19.896 & 1.142 & 9.036 & 8.211 & 6.731 & 3.43 & 12.39 & 2.657 & 0.133 \\
\hline
\end{tabular}

${ }^{a} \mathrm{n}=72$. Unstandardized regression coefficients are shown and Standard errors are in parantheses.

$+\mathrm{P}<0.1 ; * \mathrm{P}<0.05 ; * * \mathrm{P}<0.01 ; * * * \mathrm{P}<0.001$.

Table 2c. Results of the Hierarchical regression analysis estimating firm performance: EEC ${ }^{\mathrm{a}}$

\begin{tabular}{|c|c|c|c|c|c|c|c|c|c|c|c|c|}
\hline & \multicolumn{3}{|c|}{ Return on Assets } & \multicolumn{3}{|c|}{ Return on Sales } & \multicolumn{3}{|c|}{ Return on Equity } & \multicolumn{3}{|c|}{ Tobin's Q } \\
\hline & Step 1 & Step 2 & Step 3 & Step 1 & Step 2 & Step 3 & Step 1 & Step 2 & Step 3 & Step 1 & Step 2 & Step 3 \\
\hline Constant & $\begin{array}{c}-0.794 * * * \\
(.149)\end{array}$ & $\begin{array}{c}-0.773 * * * \\
(.137)\end{array}$ & $\begin{array}{c}-0.773^{* * *} \\
(.140)\end{array}$ & $\begin{array}{c}-1.169 * * * \\
(.277)\end{array}$ & $\begin{array}{c}-1.136^{* * *} \\
(.258)\end{array}$ & $\begin{array}{c}-1.035^{* * * *} \\
(.248)\end{array}$ & $\begin{array}{c}-2.281 * * * \\
(.620)\end{array}$ & $\begin{array}{c}-2.206^{* * *} \\
(.574)\end{array}$ & $\begin{array}{c}-2.158 * * * \\
(.578)\end{array}$ & $\begin{array}{c}-6.523^{* * *} \\
(2.08)\end{array}$ & $\begin{array}{c}-5.915 * * \\
(2.31) * * *\end{array}$ & $\begin{array}{c}-6.423 * * * \\
(.237)\end{array}$ \\
\hline Firm Size-Ln(Sale) & $\begin{array}{c}0.053^{* * *} \\
(.009)\end{array}$ & $\begin{array}{c}0.048^{* * *} \\
(.008)\end{array}$ & $\begin{array}{c}0.048^{* * *} \\
(.009)\end{array}$ & $\begin{array}{c}0.074 * * * \\
(.017)\end{array}$ & $\begin{array}{c}0.065^{* * *} \\
(.016)\end{array}$ & $\begin{array}{c}0.048 * * \\
(.017)\end{array}$ & $\begin{array}{c}0.158^{* * *} \\
(.037)\end{array}$ & $\begin{array}{c}0.134 * * * \\
(.035)\end{array}$ & $\begin{array}{c}0.126^{* *} \\
(.039)\end{array}$ & $\begin{array}{c}0.759^{* * * *} \\
(.175)\end{array}$ & $\begin{array}{c}0.426 \text { *** } \\
(.147)\end{array}$ & $\begin{array}{c}0.536 * * * \\
(.168)\end{array}$ \\
\hline R\&D Intensity & $\begin{array}{c}0.005^{*} \\
(.002)\end{array}$ & $\begin{array}{c}0.006^{* *} \\
(.002)\end{array}$ & $\begin{array}{c}0.006^{* *} \\
(.000)\end{array}$ & $\begin{array}{c}0.021^{* *} \\
(.007)\end{array}$ & $\begin{array}{c}0.023 * \\
(.008)\end{array}$ & $\begin{array}{c}0.019 * \\
(.008)\end{array}$ & $\begin{array}{c}0.015^{*} \\
(.007)\end{array}$ & $\begin{array}{c}0.023 * \\
(.007)\end{array}$ & $\begin{array}{c}0.019 * \\
(.008)\end{array}$ & $\begin{array}{c}0.115^{* * *} \\
(.043)\end{array}$ & $\begin{array}{c}0.178 * * * \\
(.035)\end{array}$ & $\begin{array}{c}0.113 * * \\
(.039)\end{array}$ \\
\hline Debt Leverage & $\begin{array}{l}-0.024 \\
(.040)\end{array}$ & $\begin{array}{l}-0.032 \\
(.036)\end{array}$ & $\begin{array}{l}-0.031 \\
(.037)\end{array}$ & $\begin{array}{l}0.045 \\
(.074)\end{array}$ & $\begin{array}{l}0.034 \\
(.069)\end{array}$ & $\begin{array}{l}0.051 \\
(.066)\end{array}$ & $\begin{array}{c}-0.497^{*} \\
(.225)\end{array}$ & $\begin{array}{l}-0.019 \\
(.153)\end{array}$ & $\begin{array}{l}-0.011 \\
(.155)\end{array}$ & $\begin{array}{l}-0.742 \\
(.623)\end{array}$ & $\begin{array}{l}-0.945 \\
(.630)\end{array}$ & $\begin{array}{l}-0.756 \\
(.512)\end{array}$ \\
\hline Current Ratio & $\begin{array}{l}0.001 \\
(.001)\end{array}$ & $\begin{array}{l}0.001 \\
(.001)\end{array}$ & $\begin{array}{l}0.001 \\
(.001)\end{array}$ & $\begin{array}{l}0.001 \\
(.002)\end{array}$ & $\begin{array}{l}0.001 \\
(.002)\end{array}$ & $\begin{array}{l}0.001 \\
(.002)\end{array}$ & $\begin{array}{l}-0.003 \\
(.004)\end{array}$ & $\begin{array}{l}-0.005 \\
(.004)\end{array}$ & $\begin{array}{l}-0.005 \\
(.003)\end{array}$ & $\begin{array}{c}0.043 * \\
(.017)\end{array}$ & $\begin{array}{l}0.006 \\
(.018)\end{array}$ & $\begin{array}{c}0.049 * * \\
(.016)\end{array}$ \\
\hline Market Diversification & & $\begin{array}{c}0.091 * * \\
(.027)\end{array}$ & $\begin{array}{c}0.092 * * \\
(.030)\end{array}$ & & $\begin{array}{c}0.153 * \\
(.054)\end{array}$ & $\begin{array}{c}0.058^{*} \\
(.032)\end{array}$ & & $\begin{array}{c}0.371 * * \\
(.119)\end{array}$ & $\begin{array}{c}0.352 * * \\
(.126)\end{array}$ & & $\begin{array}{c}0.456^{* * *} \\
(.213)\end{array}$ & $\begin{array}{c}0.513 * * \\
(.234)\end{array}$ \\
\hline Product Diversification & & $\begin{array}{c}-0.031 * \\
(.015)\end{array}$ & $\begin{array}{c}-0.031 * \\
(.016)\end{array}$ & & $\begin{array}{c}-0.038 * \\
(.013)\end{array}$ & $\begin{array}{c}-0.041^{*} \\
(.018)\end{array}$ & & $\begin{array}{l}-0.061 \\
(.064)\end{array}$ & $\begin{array}{l}-0.068 \\
(.070)\end{array}$ & & $\begin{array}{c}-0.248^{* *} \\
(.102)\end{array}$ & $\begin{array}{c}-0.231^{* * *} \\
(.096)\end{array}$ \\
\hline Corporate Reputation & & & $\begin{array}{l}0.001 \\
(.008) \\
\end{array}$ & & & $\begin{array}{c}0.036^{*} \\
(.014) \\
\end{array}$ & & & $\begin{array}{l}0.017 \\
(.034) \\
\end{array}$ & & & $\begin{array}{c}0.278^{* *} \\
(.102) \\
\end{array}$ \\
\hline Model R2 & 0.239 & 0.331 & 0.332 & 0.324 & 0.338 & 0.388 & 0.338 & 0.359 & 0.362 & 0.387 & 0.413 & 0.435 \\
\hline Adjusted R2 & 0.189 & 0.271 & 0.261 & 0.292 & 0.294 & 0.244 & 0.266 & 0.273 & 0.278 & 0.331 & 0.363 & 0.382 \\
\hline Model F-Ratio & $10.759^{* * *}$ & $10.72 * * *$ & $9.162 * * *$ & $18.896 * * *$ & $13.605^{* * *}$ & $14.68^{* * *}$ & $4.696^{* * * *}$ & $5.327 * * *$ & $4.612^{* * * *}$ & $8.717 * * *$ & $10.39 * * *$ & $9.747 * * *$ \\
\hline $\begin{array}{l}\text { Change in R2 } \\
\text { F-ratio for Change in }\end{array}$ & & 0.091 & 0.001 & & 0.014 & 0.045 & & 0.019 & 0.003 & & 0.026 & 0.022 \\
\hline $\mathrm{R}^{2}$ & 10.759 & 5.427 & 0.001 & 18.896 & 1.143 & 9.036 & 4.696 & 4.909 & 0.246 & 8.717 & 7.974 & 2.594 \\
\hline
\end{tabular}


Table 3. Results of the Hierarchical regression analysis estimating firm performance: USA, JAPAN, and EEC ${ }^{\text {a }}$

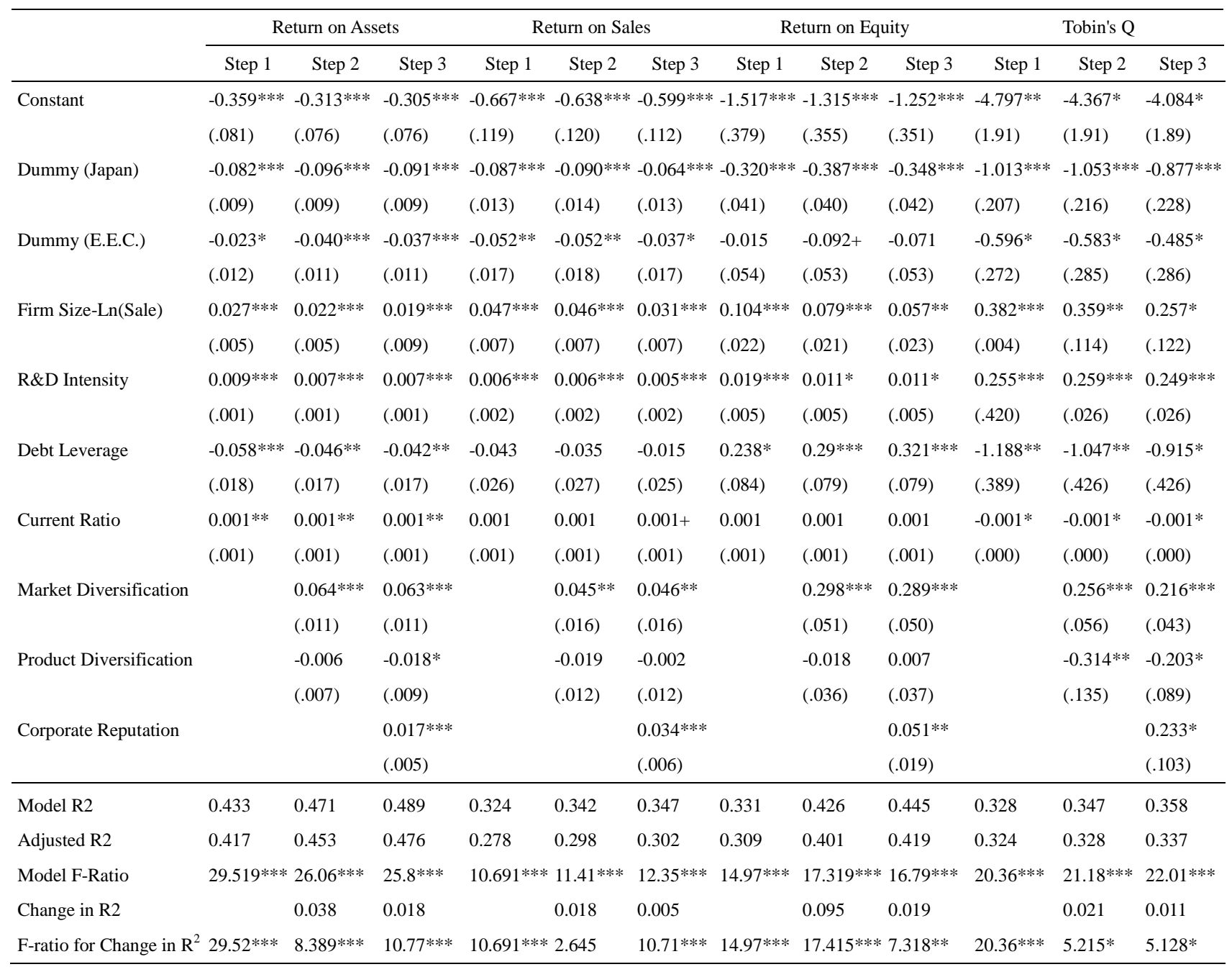

${ }^{a} n=230$. Unstandardized regression coefficients are shown and Standard errors are in parantheses.

$+\mathrm{P}<0.1 ; * \mathrm{P}<0.05 ; * * \mathrm{P}<0.01 ; * * * \mathrm{P}<0.001$

Based on an analysis of the results, a number of findings are worth highlighting. First of all, results suggest that a firm's reputation has a significant impact on its performance. Across all of the models that were tested it was determined that a favorable reputation is associated with higher levels of profitability/performance. At the very least, it is proposed that firms must recognize that corporate reputation can be a very valuable strategic resource and deserves the attention of senior executives when making strategic decisions. From a corporate management perspective the development and maintenance of a solid and highly respected corporate reputation should be a high priority on any executive's agenda. The results were consistent across all models, regardless of how performance was operationalized (either accounting- or market-based). Such a positive relationship lends credence to hypotheses $\mathrm{H}_{1}, \mathrm{H}_{1 \mathrm{a}}$, and $\mathrm{H}_{1 \mathrm{~b}}$.

Second, the same positive effect was observed for U.S. $\left(\mathrm{H}_{1 \mathrm{a}}\right)$ and Japanese $\left(\mathrm{H}_{1 \mathrm{~b}}\right)$ firms. The reputation-performance linkage seems to be a very robust relationship that spans across country boundaries, or at least to the two countries employed in the present study. Whether this relationship spans the globe or not will require further testing before we can claim that the performance-reputation relationship is a universal axiom. Due to the similarities in economic, political and social arenas, it may be that the U.S. and Japanese markets share more similarities than may be expected and therefore, do not really measure entirely different perspectives. Additionally, both countries are well developed industrialized nations, which also might indicate a level and degree of economic maturity that parallel one another.

Third, the level and type of diversification played a significant factor in explaining a firm's overall performance. 
However, the exact nature of the relationship was country-specific and the diversification type. For instance, overall market diversification was positively associated to firm performance for firm in the United States and Japan. When a product diversification strategy is followed, the results were mixed, with the U.S. reporting no relationships with performance and Japan reflecting a mixed relationship.

For Japanese firms, when the accounting-based measure ROA was used there was a negative correlation with performance. When measuring performance utilizing Tobin's Q (market-based measure) it was found that a product diversification strategy resulted in positive performance gains. Such a difference across performance measures may indicate the general overall positive expectations of firms that the introduction of a new product should lead to higher performance, which would be reflected by a market-based measure that is focused on future returns. On the other hand, the negative relationship reported when ROA was used may mirror the negative effects of product proliferation at the expense of other more financially beneficial options that are represented by market diversification. Market diversification strategies are considered to be more efficient in generating superior performance due to learning curve effects and efficiencies previously developed in domestic markets. Therefore, production and marketing synergies are easier to exploit in newer markets due to organizational familiarity, which may explain the consistent and positive association between market-based diversification and performance. When using the aggregate sample that combined both U.S. and Japanese firms, the conflicting results that were observed when firms engaged in product diversification may reflect or accentuate the overall negative effect of the U.S. firms, given that the sample size was more heavily weighted toward U.S. firms (nearly $60 \%$ of the firms in the sample were U.S. based firms).

Given these findings, there may be an overall preference in the financial markets for international diversification as opposed to product diversification. The increasing level of globalization within the business world provides a company with the opportunity to enter new countries with previously successful products that have been tested and improved in a domestic market. Past success with a product has a tendency to lower the overall risk associated with entering new markets. In order to minimize the risk that a firm is exposed to a firm may have a natural proclivity to pursue international diversification instead of product diversification. There may have been an unintended bias toward international diversification since the sample was comprised of firms form highly developed and industrialized countries; namely, the United States and Japan. The political, social, and economic stability that is enjoyed by these two countries may have affected the overall assessment of risk by financial markets.

Fourth, R\&D intensity and firm size were overwhelmingly positive in influencing a firm's performance. The relationship between firm performance and size has been found to be consistently strong throughout the strategy literature. Results on the present study are consistent with past research. However, the connection between R\&D and performance was found to be stronger for U.S. firms. Given that U.S. firms have been widely known for their use of a product innovation approach to diversification may help in explaining the strength with which U.S. firms tend to pursue a product diversification strategy. Since R\&D is an inherently risky endeavor and therefore, the outcomes of product development are highly uncertain, the attraction of expanding the geographic scope of an established and successful product may expose the firm to lower levels of risk.

Regardless of the performance measured used, R\&D intensity and firm performance have been consistently shown to be positively associated with each other. Unfortunately, given the research design employed in this study it was not possible to determine whether R\&D leads to greater profitability or profitability leads to more R\&D. Nevertheless, most research studies suggest that R\&D is the catalyst that leads to higher levels of profits. Results were consistent using a variety of performance measures. The critical nature of R\&D in determining a firm's current performance (as exemplified by ROA) and future-based performance (when using Tobin's Q) was strengthened by the results of the study.

Another interesting finding was uncovered regarding firm performance across countries. U.S. firms experienced an overall positive performance effect over the period being studied. However, the reverse was true for Japanese firms during the same period of time. Differing accounting standards among different countries may also have casused some conflicting results and conclusions, since the measures being used (Tobin's Q and accounting-based proxies) may not be perfectly comparable. Issues associated with varying international accounting standards have long been a point of contention among researchers. Cultural differences may also have been a contaminating factor in skewing the results, since not all countries share the small or even similar values. Differing values may result in the establishment of vastly different goals and objectives. The assumption of profit-driven goals across all countries may not be an accurate reflection of reality. For example, the use of short-term profitability measures, like ROA, may not be consistent with Japanese values. It is widely accepted that Japanese businesses prefer long-term benefits that will maximize the long-term viability of the company, as 
opposed to immediate or short-ranged profits. Looking at ROA from this angle would lead to vastly different conclusions.

The importance of liquidity exhibited not significant variations between countries when performance was measured using accounting-based proxies. However, when performance was viewed from a market-based perspective, liquidity exhibited a positive correlation. Such a discrepancy may indicate that while firms might not emphasize the importance of maintaining adequate levels of liquidity, that the financial markets may view this variable differently.

The impact of leverage/debt on corporate reputation reported mixed findings. Overall, when using the combined sample, leverage was negatively associated with performance when using ROA, ROS and Tobin's Q, while ROE was positively correlated with performance. Leverage was negatively correlated with ROA for Japanese firms and U.S. firms with using ROA and ROE. It was not clear exactly why these differences occurred, although they may reflect country accounting idiosyncrasies and differing perspectives on investment strategies.

\section{Conclusions, Limitations, and Issues for Future Research}

In conclusion, the findings of the present study indicate that firm reputation tends to have a positive impact on a firm's performance and that such a relationship is consistently strong across countries (U.S. and Japan). Such a finding was robust and consistent across all measures of performance. It should be noted that these results were obtained after removing the influences of product and market diversification, as well as a variety of different strategic variables (firm size, $\mathrm{R} \& \mathrm{D}$, leverage, liquidity). Based on the use of the Fortune Reputation Index it is argued that a firm's reputation serves as a key strategy variable in determining a firm's overall performance. Therefore, it is critical that senior management take an active and forceful role in the management of firm's reputation. If executives want to improve/maintain their superior performance it becomes imperative that they look toward establishing a favorable reputation. An active program for managing reputation will pay dividends to the firms that are able to establish a solid reputation.

It was observed that the impact of diversification type (international/market and product diversification) on firm performance was dependent on how performance was operationalized. Overall, firm's that pursued a product diversification strategy did not significantly benefit financially in either the United States or Japan. However, results obtained using the combined sample found market- and accounting-based measure of performance to be negatively associated with product diversification. In contrast, international/market diversification was positively correlated to performance in all models. Overall, the impact of pursing a market diversification strategy seems to be superior to increasing firm performance than following a product diversification strategy. The findings of the present study confirm and support the importance of selecting diversification strategies cautiously and deliberately when seeking to increase a company's performance.

Given the constraints associate with any research study, it is noted that there are factors and circumstances related to the present research design that may have contributed to unforeseen biases. First, variations in financial and accounting standards between countries may have had an impact on the results. Second, the selection of a five-year period may reflect uncontrollable factors that are idiosyncratic to that period. It may be the case that the effects of diversification do not show up until a longer period of time has elapsed. It would be expected that the adoption of a more lengthy time period would have revealed a richer understanding of the reputation/performance linkage. The desire of this this study is to introduce a global perspective to the reputation/performance relationship.

It is widely understood that the study of corporate reputation is a complex and multifaceted variable, with a myriad of definitions and operationalizations. Therefore, it is not possible to evaluate and examine all of the complexities of this diverse construct within the body of one research study. Similarly, the study was limited in the number of strategic control variables that could be included in the study. It is opening admitted that the final results may have been unduly influenced by the selection of control variables and that adjusting for industry effects may have strengthen the development of this body of research.

\section{References}

Amit, R., \& Livnat, J. (1988). Diversification and the risk-return tradeoff. Academy of Management Journal, 31, 154-165. http://dx.doi.org/10.2307/25650

Barney, J. (1991). Firm resources and sustained competitive advantage. Journal of Management, 17, 99-120. http://dx.doi.org/10.1177/014920639101700108

Bergh, D. D. (1995). Size and relatedness of units sold: An agency theory and resource-based perspective. Strategic Management Journal, 16, 221-239. http://dx.doi.org/10.1002/smj.4250160306 
Bettis, R. A. (1981). Performance differences in related and unrelated diversified firms. Strategic Management Journal, 2, 379-393. http://dx.doi.org/10.1002/smj.4250020406

Bettis, R. A., \& Hall, W. K. (1982). Diversification strategy, accounting risk, and accounting determined return. Academy of Management Journal, 25, 254-264. http://dx.doi.org/10.2307/255989

Brown B., \& Perry, S. (1994). Removing the financial performance halo from Fortune's "Most Admired" companies. Academy of Management Journal, 37, 1347-1359. http://dx.doi.org/10.2307/256676

Caves, R. E., \& Porter, M. E. (1977). From entry barriers to mobility barriers. Quarterly Journal of Economics, 91, 421-434. http://dx.doi.org/10.2307/1885416

Chakravarthy, B. (1986). Measuring strategic performance. Strategic Management Journal, 7, 437-458. http://dx.doi.org/10.1002/smj.4250070505

Chatterjee, S., \& Wernerfelt, B. (1991). The link between resources and type of diversification: Theory and evidence. Strategic Management Journal, 12, 33-48. http://dx.doi.org/10.1002/smj.4250120104

Conine, T. F., \& Madden, G. P. (1986). Corporate social responsibility and investment value. In W. D. Guth (Ed.), Handbook of Business Strategy, 1986/1987 Yearbook. Boston, MA: Warren, Gorham \& Lamont.

Delios, A., \& Beamish, P. W. (1999). Geographic scope, product diversification, and the corporate performance of Japanese firms. Strategic Management Journal, 20, 711-727. http://dx.doi.org/10.1002/(SICI)1097-0266(199908)20:8<711::AID-SMJ41>3.0.CO;2-8

Dess, G. G., Gupta, A., Hennart, J., \& Hill, C. W. L. (1995). Conducting and integrating strategy research at the international, corporate, and business levels: Issues and directions. Journal of Management, 21, 357-393. http://dx.doi.org/10.1177/014920639502100301

Dowling, G. R. (1986). Managing your corporate images. Industrial Marketing Management, 15, 109-115. http://dx.doi.org/10.1016/0019-8501(86)90051-9

Finkelstein, S., \& Hambrick, D. C. (1988). Chief executive compensation: A synthesis and reconciliation. Strategic Management Journal, 9, 543-558. http://dx.doi.org/10.1002/smj.4250090603

Fombrun, C., \& Shanley, M. (1990). What's in a name? Reputation building and corporate strategy. Academy of Management Journal, 33, 233-258. http://dx.doi.org/10.2307/256324

Fombrun, C. (1996). Reputation: Realizing value from the corporate image. Boston, MA: Harvard Business School Press.

Fryxell, G. E., \& Wang, J. (1994). The Fortune corporate 'Reputation' index: Reputation for what? Journal of Management, 20, 1-14. http://dx.doi.org/10.1177/014920639402000101

Geringer, M. J., Beamish, B. W., \& daCosta R. C. (1989). Diversification strategy and internationalization: Implications for MNE performance. Strategic Management Journal, 10, 109-119. http://dx.doi.org/10.1002/smj.4250100202

Geringer, M. J., Tallman, S., \& Olsen, D. M. (2000). Product and international diversification among Japanese multinational firms. Strategic Management Journal, 21, 51-80. http://dx.doi.org/10.1002/(SICI)1097-0266(200001)21:1<51::AID-SMJ77>3.0.CO;2-K

Grant, R. M., Jammine, A. P., \& Thomas, H. (1988). Diversity, diversification, and profitability among British manufacturing companies, 1972-84. Academy of Management Journal, 31, 771-801. http://dx.doi.org/10.2307/256338

Hitt, M. A., Hoskission, R. E., \& Kim, H. (1997). International diversification: Effects on innovation and firm performance in product-diversified firms. Academy of Management Journal, 40, 767-798. http://dx.doi.org/10.2307/256948

Hoskisson, R. E., Hitt, M. A., Johnson, R. A., \& Moesel, D. D. (1993). Construct validity of an objective (entropy) categorical measure of diversifications strategy. Strategic Management Journal, 14, 215-235. http://dx.doi.org/10.1002/smj.4250140305

Keats, B. W. (1990). Diversification and business economic performance revisited: Issues of measurement and causality. Journal of Management, 16, 61-72. http://dx.doi.org/10.1177/014920639001600105

Kim, C. W., Hwang, P., \& Burgers, W. P. (1989). Global diversification strategy and corporate profit performance. Strategic Management Journal, 10, 45-57. http://dx.doi.org/10.1002/smj.4250100105 
Klein, B., \& Leffler, K. (1981). The role of market forces in assuring contractual performance. Journal of Political Economy, 89, 615-641. http://dx.doi.org/10.1086/260996

Lang, L. H. P., \& Stulz, R. M. (1994). Tobin's q, corporate diversification, and firm performance. Journal of Political Economy, 102(6), 1248-1280. http://dx.doi.org/10.1086/261970

Lee, J., \& Hall, Jr., E. H. (2008). An Empirical Investigation of the 'Halo' Effect of Financial Performance on the Relationship between Corporate Reputation and CEO Compensation. American Journal of Business Research, 1(1), 93-110.

Lippman, S. A., \& Rumelt, R. P. (1982). Uncertain Imitablity: An analysis of interfirm differences in efficiency under competition. Bell Journal of Economics, 13, 418-438. http://dx.doi.org/10.2307/3003464

Lu, J. W., \& Beamish, P. W. (2004). International diversification and firm performance: The S-curve hypothesis. Academy of Management Journal, 47(4), 598-609. http://dx.doi.org/10.2307/20159604

McGuire, J., Sundgren, A., \& Schneeweis, T. (1988). Corporate social responsibility and firm financial performance. Academy of Management Journal, 31, 854-872. http://dx.doi.org/10.2307/256342

Milgrom, P., \& Roberts, J. (1986). Price and advertising signals of product quality. Journal of Political Economy, 94, 796-821. http://dx.doi.org/10.1086/261408

Miller, D. J. (2004). Firms' Technological Resources and the Performance Effects of Diversification: A Longitudinal Study. Strategic Management Journal, 25, 1097-1119. http://dx.doi.org/10.1002/smj.411

Palepu, K. (1985). Diversification strategy, profit performance and the entropy measure. Strategic Management Journal, 6, 239-255. http://dx.doi.org/10.1002/smj.4250060305

Palich, L. E., Cardinal, L. B., \& Miller, C. C. (2000). Curvilinearity in the diversification-performance linkage: An examination of over three decades of research. Strategic Management Journal, 21, 155-174. http://dx.doi.org/10.1002/(SICI)1097-0266(200002)21:2<155::AID-SMJ82>3.0.CO;2-2

Porter, M. E. (1990). The competitive advantage of nations. Harvard Business Review, March-April, 73-93.

Preston, L. E., \& Sapienza, H. T. (1990). Stakeholder management and corporate performance. Journal of Behavioral Economics, 19, 361-375. http://dx.doi.org/10.1016/0090-5720(90)90023-Z

Roberts, R. W., \& Dowling, G. R. (2002). Corporate reputation and sustained superior financial performance. Strategic Management Journal, 23, 1077-1093. http://dx.doi.org/10.1002/smj.274

Rugman, A. M. (1979). International diversification and the multinational enterprise. Lexington, MA: Lexington Books.

Rumelt, R. P. (1974). Strategy, Structure, and Economic Performance. Cambridge: MA:Harvard University Press.

Rumelt, R. P. (1982). Diversification strategy and profitability. Strategic Management Journal, 3, 359-369. http://dx.doi.org/10.1002/smj.4250030407

Shrum, W., \& Wuthnow, R. (1988). Reputational status of organizations in technical systems. American Journal of Sociology, 93, 882-912. http://dx.doi.org/10.1086/228828

Tallman, S., \& Li, J. (1996). Effects of international diversity and product diversity on the performance of multinational firms. Academy of Management Journal, 39, 179-196. http://dx.doi.org/10.2307/256635

Wilson, R. (1985). Reputations in games and markets. In A. E. Roth (Ed.), Game theoretic models of bargaining (pp. 65-84). New York: Cambridge University Press. http://dx.doi.org/10.1017/CBO9780511528309.004

Wolf, B. M. (1975). Size and profitability among U. S. manufacturing firms: Multinational versus primarily domestic firms. Journal of Economics and Business, 28, 15-22.

\section{Copyrights}

Copyright for this article is retained by the author(s), with first publication rights granted to the journal.

This is an open-access article distributed under the terms and conditions of the Creative Commons Attribution license (http://creativecommons.org/licenses/by/3.0/). 